Title: Coastal residents' literacy about seawater desalination and its impacts on marine ecosystems in California

Authors:

Nadine Heck (corresponding author)

Institute of Marine Sciences, University of California, Santa Cruz, 1156 High Street, Santa Cruz CA 95064, USA, nheck@ucsc.edu

\title{
Adina Paytan
}

Institute of Marine Sciences, University of California, Santa Cruz, 1156 High St., Santa Cruz, CA 95064, USA and Department of Earth and Planetary Sciences, University of California, Santa Cruz, 1156 High Street, Santa Cruz, CA 95064, USA, apaytan@ucsc.edu.

Donald C. Potts

Department of Ecology and Evolutionary Biology, University of California, Santa Cruz, 1156 High St., Santa Cruz, CA 95064, USA, potts@ucsc.edu.

\section{Brent Haddad}

Environmental Studies, University of California, Santa Cruz, 1156 High St., Santa Cruz, CA 95064, USA, bhaddad@ucsc.edu. 


\section{Introduction}

Public knowledge about ocean issues and management is typically low, despite the high percentage of the human population that lives in coastal areas [e.g., 1, 2, 3]. Because direct experiences of marine environments often require specialized training (e.g., scuba diving, boating, fishing etc.) [4], people engage with marine areas in very different ways compared to terrestrial ecosystems, and this may factor into public knowledge about marine areas and resources [5]. Compared to terrestrial areas, impacts on marine areas are also less visible and might be less known and understood by the public [6-9]. To address these deficiencies, there have been calls for increasing public understanding of coastal and marine ecosystems and how these systems are affected by human uses [10-13].

\subsection{Public knowledge about the ocean and its resources}

Public knowledge about the ocean and its resources is critical for multiple reasons. Many people are either directly or indirectly involved in activities and behaviors that have negative impacts on the ocean and coastal areas $[14,15]$. Public literacy about the ocean and its resources is vital as it may shape individual activities and behaviors that add to or reduce pressure on marine areas $[1$, 16]. Ocean literacy is also important for policy decisions on the use and protection of ocean resources and ecosystems $[17,18]$. Coastal citizens can have significant influences in decisionmaking processes and they need to be literate about ocean issues if they are to engage in policy discussions in an informed way $[1,8]$. The recent National Ocean Policy emphasized this point and called for an increase in ocean and coastal literacy to empower coastal communities to become better stewards of ocean resources [13]. Assessing public literacy and identifying factors that increase policy-relevant knowledge is critical for identifying misconceptions and knowledge gaps, and for tailoring communication and outreach programs.

Two theories have been proposed to explain differences in public knowledge. One theory focuses on 'trans-situational' socio-economic variables that apply in multiple settings (e.g., level of formal education, income, education, age, or gender) $[8,19]$. A second theory suggests that knowledge acquisition is shaped by situation-specific variables that can increase knowledge irrespective of citizens' socio-economic status [20,21]. Situational factors are more motivational in character and might increase knowledge-seeking behavior by having a stake in a policy outcome, or having strong views on specific policies [22, 23]. For example, people who live on 
the coast, visit the ocean for recreation or commercial purposes, or have a strong attachment to ocean areas might be very interested in the management of marine resources, seek more information on ocean management issues, and subsequently may be highly knowledgeable in these areas $[1,23,24]$.

To understand public literacy about the ocean, it is also important to identify where people acquire information about marine issues. Television and the Internet, for example, are popular used sources for information on environmental topics, but many citizens and scientists question the reliability of information provided in these media [25-27]. The Internet, for example, offers excellent resources for learning about ocean and coastal issues and impacts of specific human activities (e.g., Sea Grant and NOAA websites) [e.g., 28, 29, 30]. At the same time, information on the Internet can be inaccurate and/or reflect subjective opinions [1]. Understanding where people learn about the ocean is critical for tailoring communication strategies and ensuring that credible information reaches the public and subsequently increases ocean literacy.

To date, research on public knowledge about the ocean and its resources is very limited. Previous studies investigated ocean literacy among high school students [31] and the influence of attitudes towards science and ocean stewardship on ocean literacy among teenagers [32]. Studies on general public knowledge have investigated awareness of coastal and marine environmental issues [9], and the influences of proximity of residence to the ocean, use of information sources, environmental values, and socio-demographic variables on knowledge about the ocean [1, 7]. A study by Perry et al. [33] investigated knowledge about marine protected areas. The authors assessed the influence of coastal vs. inland residency and place attachment on public knowledge about marine protected areas in Oregon. Our study builds on the existing literature and investigates the level of public literacy about the impacts of seawater desalination on marine ecosystems in a coastal community in Southern California.

\subsection{Seawater desalination and its impacts on marine ecosystems}

Seawater desalination is an emerging sector in the USA that is likely to grow in the future. Coastal areas that rely on imported water or groundwater resources are increasingly experiencing water shortages due to changes in weather patterns, recurring droughts, and increased water 
demand for municipal and industrial purposes [34-36]. In addition, saltwater intrusion, due to over pumping and depletion of groundwater, is likely to be aggravated by rising sea level in coastal areas [37]. In response to these concerns and statewide funding initiatives, about 15 seawater desalination projects have been proposed along the southern and central coast of California [38-40]. [38-40]. California is currently the state with the highest number of proposed seawater desalination plants in the United States [41-44]. A number of proposed plants will have capacities of up to 50 million gallons per day (mgd) compared to capacities of 0.02-0.6 million gallons per day (mgd) of most existing plants [38, 45].

Even though seawater desalination is highly valued because of its independence of climate, the technology remains controversial due to high costs and potential environmental impacts in particular [46-48]. Environmental concerns about direct impacts on coastal ecosystems include mortality of marine life due to impingement and entrainment during water intake. An additional concern is the discharge of brine. Brine is generated as a by-product of desalination and may be twice the salinity of ocean water, if not diluted prior to discharge into the ocean [38]. Potential impacts of brine discharge include mortality of marine life (particularly larvae), changes in seawater quality, impacts on fish resources, degradation of marine habitats due to toxic concentrations of brine, anoxic or hypoxic conditions, and stress from turbulent mixing at the point of discharge [38, 41, 49-52].

These concerns about impacts on marine areas have contributed to the slow development of desalination plants in California. To date, only one high capacity plant has been constructed and it began operation in December 2015. As part of the planning process, coastal residents and interest groups have the opportunity to comment on environmental impact reports and local decisions about the development of new plants. Subsequently, these groups need to be literate about desalination to engage in informed discussions. Yet, public literacy about this new sector and its impacts on marine ecosystems is unknown. Our paper addresses this point by investigating the level of public awareness of desalination and the variables that increase public knowledge. The specific objectives of this paper are: (1) to determine the level of policy-relevant awareness and knowledge about brine discharge and its impacts on the ocean; (2) to identify socio-demographic factors, situation-specific factors, and information sources associated with 
higher levels of knowledge; and (3) to assess the relationship between knowledge and attitude towards seawater desalination.

2. Methods

\subsection{Study area}

Our case study is the newly constructed desalination plant in Carlsbad, a seaside town of 109,318 residents in Southern California that is part of the San Diego County Water authority district (Fig. 1). The offshore marine area adjacent to the plant site is part of the geographic zone known as the Southern California Bight (SCB), which encompasses about 56,979 $\mathrm{km}^{2}$ (22,000 square miles) from Point Conception in the north to Cabo Colnett in Baja California in the South [53]. The coast adjacent to the plant consists of 50-70 m wide beaches backed in places by 12-24 $\mathrm{m}$ marine terrace bluffs. Important habitats in the area include intertidal sand habitats, subtidal soft bottom habitats, and subtidal hard bottom habitats. Abundant benthic organisms in soft bottoms include clams, snails, polychaete worms, arthropods (crabs and shrimps), fishes and offshore kelp beds, while the nearshore water column contains pelagic fishes, phytoplankton and zooplankton.

Fig. 1 near here

Freshwater supply in the area depends heavily on imported water. The San Diego water district receives about $64 \%$ of its drinking water from the Colorado River, approximately $20 \%$ from the state water project in Northern California, and only 16\% from local sources [54]. The supply from imported resources has become increasingly unreliable due to changing weather patterns, including reduced snowpack in the Sierra Nevada, less precipitation, and continued drought conditions [35]. To diversify its water portfolio, the San Diego Water Authority entered a 30year agreement with a private investor, Poseidon Resources, to purchase 56,000 acre-feet of desalinated water per year from the Carlsbad desalination plant [55]. This desalinated water will increase local supply to about 26 percent. The desalination plant is a 1 billion dollar project that will increase water price for homeowners by about $\$ 5$ per month [56]. Development of the plant began in 1998 and, after multiple delays in the permitting process, the plant started operation in December 2015. 
At full capacity, the desalination plant will use about 300 million gallons (mgd) of seawater every day via open ocean intake technology [57, 58]. The reverse osmosis desalination process will use $100 \mathrm{mgd}$ to produce $50 \mathrm{mgd}$ of high quality drinking water and $50 \mathrm{mgd}$ of salty brine (with a concentration of about 67,000 ppm, twice the concentration of incoming seawater). The remaining $200 \mathrm{mgd}$ of seawater will dilute the brine before discharge into the ocean [59]. The plant shares the existing seawater intake and outfall infrastructure of the Encina power plant located next to the new desalination plant.

\subsection{Mail survey}

Data on public awareness and knowledge were collected via a questionnaire-based survey between March and May 2015. Questionnaires were administered by mail to a sample of 1,500 residents in Carlsbad, California. The sample was randomly selected from postal records. Questionnaires were administered using three mailings, following Dillman et al. [60]. The first and third mailings consisted of a cover letter, booklet style questionnaire, and prepaid return envelope. The second mailing was a postcard reminder sent to residents who had not responded to the first mailing. The third mailing was sent only to addresses that had not responded to the survey or were returned as undeliverable in the first or second mailings [61]. The total sample size was 330 with a response rate of $25 \%$ after accounting for undeliverable mail $(n=159)$. This response rate is consistent with mail surveys asking the public about natural resource issues [33, $61,62]$.

Similar to previous studies on public knowledge [1, 33], residents' literacy about marine impacts of the desalination plant was assessed based on three indicators: (1) public awareness of the plant and brine discharge; (2) self-assessed level of knowledge about impacts from the plant; and (3) factual knowledge about brine discharge, including composition of the brine, location of discharge, and movement of brine in the ocean. The distinction between self-assessed and factual knowledge is important since knowledge is usually highly subjective [63]. Self-assessed knowledge is measured by assessing what a person believes he or she knows. Factual knowledge is measured by assessing if a person knows the correct answers to specific knowledge questions [33].

The questionnaire contained closed questions on residents' awareness with a yes/no choice asking about awareness of the plant and the brine discharge. The level of self-assessed 
knowledge for five items was measured on a 5-point scale from $0=$ do not know to $4=$ very high level of knowledge. Factual knowledge was measured based on a list of 11 knowledge items. The items were listed as statements and people were asked to agree, disagree, or indicate that they do not know for each item. The list was based on information in the peer-reviewed and gray literature, including environmental impact reports and government reports on brine discharge in California.

Independent variables included socio-demographic information on gender, level of education, years living in the community, and age (Table 1). Motivational variables (Table 2) included frequency of undertaking five marine activities in the area on a 5-point scale from $1=$ never to 5 $=$ almost every day. Similar to the study by Perry et al. (2014), place attachment was measured based on three items on place identity (emotional ties to a place related to its symbolic meanings) and three items on place dependence (functionality associated with an area, represented by its tangible physical characteristics and attributes) [64]. These variables were measured on a 5-point scale from $1=$ strongly disagree to $5=$ strongly agree. The questionnaire also included a yes/no question about membership in an environmental NGO. Use of information sources was assessed based on how frequently people used 15 information sources to learn about the local desalination plant on a 3 -point scale from $1=$ never to $3=$ very often. In addition, residents were asked to check the 3 most trusted information sources. All statistical analyses were conducted using IBM SPSS.23.

Table 1 and 2 near here

\section{Results}

3.1 Awareness and knowledge about impacts of seawater desalination on marine ecosystems For the first indicator, awareness, the majority of coastal residents in our study $(94.1 \%)$ were aware of the desalination plant (Fig. 2), yet fewer than half the respondents (48.7\%) reported that they were aware that the plant discharges brine after the water is desalinated.

For the second indicator, self-assessed knowledge, respondents indicated lower levels of knowledge about the brine discharge (62.4\%) and associated impacts on the ocean (56.7\%) (Fig. 
3). The low level of self-assessed knowledge extended to the price of desalinated water, the desalination process, and energy demand for the plant (Fig. 4).

Fig 2-4 near here

For the third indicator, factual knowledge, more than half the respondents answered 2 out of 11 items correctly: that the brine contains salt (83.2\%) and dead marine organisms (52.2\%) (Table 3). $49 \%$ of respondents also knew that the salt content of brine differs from that of the ocean water. For all other eight items, the percentage of respondents who answered correctly was considerably less than 50\%. In addition, the number of incorrect responses was relatively low for all 11 items. In fact, the proportion of "do not know" responses was higher for all questions than the number of incorrect answers, and nine of 11 items had more than 50\% "do not know" responses. Respondents thus either gave the correct answer or were aware that they did not know if the statement was true or false. Correlation analysis further revealed that factual and selfassessed knowledge were positively correlated (Table 4). Respondents with low factual knowledge thus seem to be aware that they did not possess a high level of knowledge about the desalination plant and its impacts on the local marine environment.

Table 3 and 4 near here

3.2 Where do people learn about seawater desalination?

The use of information sources to learn about desalination was low (Fig. 5 and Fig. 6). Residents most frequently learned about the plant from newspapers, the internet, and TV, but they had the greatest trust in information from newspapers and public hearings (Fig. 5). When asked about the providers of information, residents learned most often about the plant from friends and family, environmental NGOs, and the San Diego Water Authority, even though they trusted scientist the most to provide accurate information (Fig. 6). For many items, frequency of information use was not related to trust in the source.

Fig 5 and 6 near here

3.3 Factors that increase public awareness and knowledge A non-parametric correlation analysis was conducted to understand which variables increase awareness and knowledge, including socio-demographic, motivational, and information variables (Table 5). 


\subsubsection{Socio-demographics}

Gender correlated negatively with all three indicators, suggesting that male respondents were more aware $(\mathrm{r}=-2.30, \mathrm{p}<0.01)$ and more knowledgeable than female residents $(\mathrm{r}=-2.77, \mathrm{p}<$ 0.01 , and $\mathrm{r}=-2.70, \mathrm{p}<0.01$ ). Age and residential time in Carlsbad only correlated with awareness and self-assessed knowledge. Older respondents were slightly more aware of the plant than younger ones $(r=0.136, p<0.05)$. Residents who have lived in the community for a long time were more aware of the plant $(\mathrm{r}=0.195, \mathrm{p}<0.01)$ and had a higher level of self-assessed knowledge $(r=0.234, p<0.01)$. Education did not correlate with any indicator, suggesting that higher educational achievement did not increase awareness or knowledge about the plant and its environmental impacts.

Table 5 near here

\subsubsection{Situation-specific motivational variables}

Frequency of ocean use and membership in an environmental NGO correlated positively with awareness and knowledge. People engaging frequently in marine activities in the area were more aware of the plant $(r=0.129, \mathrm{p}<0.05)$, and had higher self-assessed $(\mathrm{r}=0.170, \mathrm{p}<0.01)$ and factual knowledge $(r=0.197, p<0.01)$ than other residents. Membership in environmental NGOs increased awareness $(r=0.124, p<0.05)$ and self-reported knowledge $(r=0.159, p<$ $0.01)$, but not factual knowledge $(r=0.102, p>0.05)$. Place attachment correlated negatively with self-assessed knowledge. Residents who felt very attached to local marine areas reported lower self-assessed knowledge about impacts on the local marine ecosystem than residents who felt less attached to local marine areas $(r=10.181, \mathrm{p}<0.01)$.

\subsubsection{Information use}

Frequency of information use correlated positively and significantly with both awareness and self-assessed knowledge for all but one of 15 information sources. The exception was social media, which had positive but not significant correlations with both indicators.

The correlation of frequency of use with factual knowledge was more varied. While all correlations were positive, only half (8) significantly increased factual knowledge. Six sources (newspapers, internet, radio, scientists, environmental NGOs, and government) strongly 
correlated with increased factual knowledge (all $\mathrm{p}<.01$ ). Two sources, anti-desalination groups and the water industry, did not correlate strongly (both $\mathrm{p}<0.05)$ (Table 5).

Table 5 near here

Public hearings that are often used to educate the public about issues relevant to policy did not increase factual knowledge $(r=0.074, \mathrm{p}>0.05)$. These venues only raised awareness of the plant without increasing factual knowledge.

Regression analysis reveals that when a number of independent variables are combined, they can predict a fair amount of awareness $\left(R^{2}=0.305\right)$, self-assessed knowledge $\left(R^{2}=0.396\right)$, and factual knowledge $(\mathrm{R}=0.385)$ (Table 6 and Table 7). Gender and information use remain the only predictors across all three indicators. Ocean use was also predicative for factual knowledge. Table 6 and 7 near here

The influence of awareness and knowledge on attitude towards the seawater desalination plant Binary regression analysis revealed that factual knowledge and awareness of brine discharge both influenced attitudes towards the plant (Table 8). Coastal residents who were aware of brine discharge and had high factual knowledge about marine impacts were less supportive of the new facility.

Table 8 near here

\section{Discussion}

This paper explores coastal residents' awareness and knowledge about potential impacts on the marine ecosystem from a newly constructed seawater desalination plant in Carlsbad, California. More than $50 \%$ of respondents in our study were not aware that the desalination plant will discharge brine and only two out of 11 questions about brine composition, location of discharge and impacts on the marine ecosystem from the plant had more than $50 \%$ correct responses. In fact, with the exception of three questions, all knowledge items had the highest percentage for the "do not know" answer choice to factual questions. The data suggest very little knowledge about the concept of desalination in general and its environmental implications in particular among coastal residents in our study. 
The low level of factual knowledge is similar to studies of public knowledge about other marine topics $[8,33,65,66]$. The limited factual knowledge in our study might stem from seawater desalination being a recent ocean use in Southern California. The newness of a marine issue, however, usually heightens its exposure in the media (Murphy 2010), and this was also the case for the desalination facility in our study [e.g., 67, 68, 69]. Subsequently, people might feel at least aware and knowledgeable even though their actual knowledge might be low [33]. In contrast to findings in previous studies of public knowledge about ocean related issues [7, 8, 33], reported self-assessed knowledge was not higher than factual knowledge, and both had low scores. The lack of self-assessed knowledge was not restricted to impacts on marine ecosystems since respondents in our study felt that they know very little about the desalination process and its environmental and economic impacts.

Further analysis revealed that people who frequently sought information about the plant reported greater awareness and self-assessed knowledge, irrespective of the information sources. Since almost all media sources, with the exception of social media, were positively correlated with greater awareness, it appears that a diversity of media sources can be used to foster awareness of desalination, a new technology and ocean sector. The finding also suggests that people might not use social media to learn about the desalination or the ocean since these media did not even increase awareness of the plant or brine discharge in our study. However, social media, such as Twitter or Facebook have great potential to inform the public about marine issues, e.g. by following environmental and marine organizations (e.g., NOAA or Sea Grant). Future research could investigate the potential of particular social media for increasing ocean literacy.

Few information sources actually increased factual knowledge; these were mainly newspapers, the Internet, and radio. The effectiveness of newspapers and the Internet for increasing public literacy about ocean issues was also reported in previous studies [1, 8]. In contrast to Steel et al. (2005), no information source in our study correlated negatively with knowledge and adversely affected knowledge about the plant. Our findings also reveal that information provided by scientists, environmental groups, anti-desalination groups, and state government agencies (e.g., Department of Water Resources, State Water Resources Control Board) increased factual knowledge about desalination, whereas attending public hearings did not. This has important implications, as government agencies often use public hearings to inform the public about new 
coastal and marine developments and to elicit public opinions about the issues. Based on our findings, these venues are currently not effective in increasing public literacy about seawater desalination and its impacts on marine ecosystems.

Among socio-demographic variables, male respondents were more aware and knowledgeable than females. This gender gap is consistent with previous research on public knowledge about policy-relevant issues [8]. Other socio-demographic factors, including age and education, did not affect factual knowledge. Therefore, except for gender, socio-demographic characteristic did not explain differences in knowledge in our study.

People who engage frequently in marine activities were both more aware and more knowledgeable. This confirms that situation-specific variables, such as use of marine environments, increase policy-relevant knowledge about marine issues. Steel et. al. [8] also found that personal visits or business interests are factors conducive to acquisition of knowledge about coastal and ocean resources. Therefore creating more opportunities for the public to engage in marine activities, and enhancing education and outreach programs with activity-based elements, in addition to the distribution of information, may significantly enhance public literacy about marine issues. These could be a critical ways for developing public ocean stewardship, since knowledge shapes behavior and attitudes towards the ocean $[1,16]$.

Residents who were members of environmental NGOs reported high self-assessed knowledge but they did not have a high level of factual knowledge. Information provided by environmental NGOs may instill a feeling of knowledge that is not necessarily matched by factual knowledge of the issues. Passive membership in an organization may be less effective for increasing ocean literacy than active engagement in marine activities.

Our study also tested whether place attachment to marine areas increases knowledge about potential threats and impacts on marine ecosystems from desalination plants, since people might retain more information about areas they feel attached to [70]. In our case, place attachment to local marine areas did not correlate significantly with awareness and factual knowledge, indicating that people with higher place attachment did not know more about impacts on the marine ecosystem than residents with lower place attachment. In addition, place attachment correlated negatively with reported self-assessed knowledge. Perry et al. (2014) reported a similar lack of influence of place attachment on knowledge for marine protected areas. Our study 
thus adds to mixed findings on the relationship between place attachment and knowledge, in particular for marine areas [33, 70,71]. Perry et al. (2014) suggest that people may connect to marine areas in a different way compared to terrestrial areas, and that factors other than place attachment might increase knowledge retention about marine areas. In our study, for example, active engagement in marine activities had a more significant influence on knowledge than place attachment. Additional empirical research comparing the influence of place attachment on knowledge with other variables could clarify this point.

Factual knowledge about the plant and its impacts correlated negatively with support for the new desalination plant. Residents who knew more about environmental impacts were less supportive of the plant than residents who knew less about it. This finding confirms that public literacy is an important factor in individual decision making and attitude formation about policy issues [8]. Increasing public knowledge is thus essential to facilitate meaningful and informed discussions with the public e.g., during public hearings. Current efforts seem inadequate to allow for meaningful engagement of citizens. In addition, increasing public literacy about impacts on marine areas may instill a sense of ocean stewardship, or at least increase calls for more environmentally friendly technologies. In the case of seawater desalination, multiple options exist to reduce impacts on the ocean (e.g., subsurface water intake, diffusers for brine discharge etc.). Less support for plants affecting marine ecosystems, due to increased public knowledge about these issues, could foster the development of desalination plants that add less stress to marine environments and increase sustainable use of ocean resources.

\section{Conclusions}

Our findings confirm that current ways of raising awareness and knowledge among the public about coastal and marine issues are inadequate [72]. As the use of seawater desalination to improve reliability of freshwater supply in coastal areas is likely to increase in the future, there is a great need for more public education. Our study suggests the public currently lacks an understanding of even basic concepts about this new ocean sector. Targeted education and outreach efforts will be critical for addressing this knowledge gap.

In addition, research is needed to identify the influence of additional variables that increase policy-relevant knowledge of new ocean sectors, such as seawater desalination. Such studies could also include economic, technological, and social issues surrounding desalination that were 
beyond the scope of our study. Future studies could also determine to what extent findings in this study apply to particular stakeholder groups that may be involved in policy- and decisionmaking on desalination plants (e.g., marine users groups, recreation interest groups, commercial interest groups, environmental NGOs, and resource managers).

\section{Acknowledgements}

The study was funded under the National Science Foundation Coastal SEES program, award 1325649.

\section{References}

1. Steel, B.S., et al., Public ocean literacy in the United States. Ocean \& Coastal Management, 2005. 48(2): p. 97-114.

2. Parnell, P., et al., Effectiveness of a small marine reserve in southern California. Marine Ecology Progress Series, 2005. 296: p. 39-52.

3. Snider, A., et al., Factors Affecting Knowledge, Perceptions, and Attitudes Regarding North Carolina Coastal Reserve Management. Coastal Management, 2010. 38(5): p. 540-558.

4. Knowlton, N. and J. Jackson, The ecology of coral reefs. Marine community ecology. Sinauer Associates, Sunderland, 2001: p. 395-422.

5. Duda, M., et al., California Residents' Opinions on and Attitudes Toward Coastal Fisheries and their Management, 2007, Responsive Management: Harrisonburg, Virginia.

6. Compas, E., et al., Murky waters: Media reporting of marine protected areas in South Australia. Marine Policy, 2007. 31(6): p. 691-697.

7. Beldon Russonello Stewart and American Viewpoint, Communicating about Oceans: Results of a National Survey, 1999: Washington DC.

8. Steel, B., et al., Correlates and Consequences of Public Knowledge Concerning Ocean Fisheries Management. Coastal Management, 2005. 33(1): p. 37-51.

9. Fletcher, S., et al., Public awareness of marine environmental issues in the UK. Marine Policy, 2009. 33(2): p. 370-375.

10. Pew Oceans Commission, America's Living Oceans: Charting a Course for Sea Change. A Report to the Nation, 2003, Pew Oceans Commission: Arlington, VA.

11. US Commission on Ocean Policy, An Ocean Blueprint for the 21st Century. Report of the US Commission on Ocean Policy 2004, US Commission on Ocean Policy: Washington SC.

12. Daigle, D., Involving the public in coastal conservation, in Values at Sea, D. Dallmeyer, Editor. 2003, University of Geogia Press: Athens, GA.

13. National Ocean Council, National Ocean Policy Implementation Plan, 2013, National Ocean Council,: Washington, D.C.

14. Voyer, M., et al., 'It's part of me'; understanding the values, images and principles of coastal users and their influence on the social acceptability of MPAs. Marine Policy, 2015. 52: p. 93-102.

15. Jefferson, R., et al., Understanding audiences: Making public perceptions research matter to marine conservation. Ocean \& Coastal Management, 2015. 115: p. 61-70. 
16. Hynes, S., D. Norton, and R. Corless, Investigating societal attitudes towards the marine environment of Ireland. Marine Policy, 2014. 47(0): p. 57-65.

17. Beierle, T.C. and J. Cayford, Democracy in practice: Public participation in environmental decisions. 2002: Resources for the Future.

18. McKinley, E. and S. Fletcher, Improving marine environmental health through marine citizenship: A call for debate. Marine Policy, 2012. 36(3): p. 839-843.

19. Lovrich, N. and J. Pierce, "Knowledge gap" phenomena: Effect of Situation-Specific and Transsituational Factors. Communication Research, 1984. 11(3): p. 415-434.

20. Pierce, J., N. Lovrich, and R. Dalton, If the truth hurts, consider the source: public trust of environmental information about nuclear facilities in Russia and the United States, in Handbook of Global Environmntal Policy and Administration, D. Soden and B. Steel, Editors. 1999, Marcell Dekker: New York.

21. Ettema, J.S. and F.G. Kline, Deficits, Differences, and Ceilings: Contingent Conditions for Understanding the Knowledge Gap. Communication Research, 1977. 4(2): p. 179-202.

22. Pierce, J.C., Citizens, political communication, and interest groups: Environmental organizations in Canada and the United States. 1992: Praeger Publishers.

23. Steel, B.S., D.L. Soden, and R.L. Warner, The impact of knowledge and values on perceptions of environmental risk to the great lakes. Society \& Natural Resources, 1990. 3(4): p. 331-348.

24. Duda, M., et al., California Residents' Opinions on and Attitudes Toward Coastal Fisheries and their Management, 2007, Responsive Management: Harrisonburg, VA.

25. Pierce, J.C., If the Truth Hurts, Consider the Source. Handbook of Global Environmental Policy and Administration, 1999. 74: p. 433.

26. Steel, B., N. Lovrich, and J. Pierce, Trust in natural resource information sources and postmaterialist values: A comparative study of U. S. and Canadian citizens in the Great Lakes area. Journal of Environmental Systems, 1992. 22(2): p. 123-136.

27. Koene, A., et al. Research Ethics and Public Trust, Preconditions for Continued Growth of Internet Mediated Research. in 1st International Conference on Information System Security and Privacy (ICISSP). 2015.

28. Sea Grant USC. Ocean, Science, \& Environmental Literacy. 2015 10-07-15]; Available from: https://dornsife.usc.edu/uscseagrant/literacy/.

29. NOAA Office of Education, Ocean Literacy. Essential Principles and Fundamnetal Concepts of Ocean Sciences for Learners of All Ages. , 2013, NOAA's Office of Education and the National Marine Sanctuary Foundation.

30. Alaska Sea Grant. Alaska Sea Grant's Marine Education Resources. 2015 10-07-15]; Available from: https://seagrant.uaf.edu/marine-ed/.

31. Greely, T., Ocean literacy and reasoning about ocean issues: The influence of content, experience and morality. 2008.

32. Cudaback, C., Ocean literacy: there's more to it than content. Oceanography, 2008. 21(4): p. 1011.

33. Perry, E.E., et al., Coastal resident knowledge of new marine reserves in Oregon: The impact of proximity and attachment. Ocean \& Coastal Management, 2014. 95: p. 107-116.

34. Bourne, G., California Desalination Planning Handbook, 2008, Sacramento: Center for Collaborative Policy: California State University Sacramento.

35. Mirchi, A., et al., Climate Change Impacts on California's Water Resources, in Drought in Arid and Semi-Arid Regions, K. Schwabe, et al., Editors. 2013, Springer Netherlands. p. 301-319.

36. Sellers, J., Desalination policy in a multilevel regulatory state, in Desalaction de agua con energias renovables, C.N. Escuder and G.H.L. Bert, Editors. 2008, National Autonomous University of Mexico Press: Mexico City. p. 173-188. 
37. Heberger, M., et al., The Impacts of Sea-Level Rise on the California Coast, 2009, California Climate Change Center.

38. State Water Resources Control Board, Amendment to the Water Quality Control Plan For Ocean Waters of California. Draft Staff Report Including the Draft Substitute Environmental Documentation, C.E.P. Agency, Editor 2014, State Water Resources Control Board: Sacramento.

39. Pacific Institute, Proposed Seawater Desalination Plants in California., 2012, Pacific Institute: Oakland.

40. Seller, J., Desalination policy in a multilevel regulatory state. In Desalaction de agua con energias renovables, C. Escuder and G. Bert, Editors. 2008, National Autonomous University of Mexico Press.: Mexico City. p. 173-188.

41. Monterey Bay National Marine Sanctuary and National Marine Fisheries Service. Guidelines for Desalination Plants in the Monterey Bay National Marine Sanctuary. 2010 06-21-15]; Available from: http://montereybay.noaa.gov/resourcepro/resmanissues/pdf/050610desal.pdf.

42. California Coastal Commission, Seawater Desalination and the California Coastal Act, C.C. Commission, Editor 2004: San Francisco, CA.

43. State of California Public Utilities Commission, Am Monterey Peninsula Water Supply Project, 2015, California Public Utilities Commission.

44. Peel, J. and J. Choy, Water Governance and Climate Change. Drought in California as a Lens on Our Climate Future, 2014, Stanford Woods Institute for the Environment: Stanford.

45. Kelley, A., Seawater desalination: climate change adaptation strategy or contributor? ECOLOGY LAW CURRENTS, 2011. 38: p. 40-50.

46. Liu, T.-K., H.-Y. Sheu, and C.-N. Tseng, Environmental impact assessment of seawater desalination plant under the framework of integrated coastal management. Desalination, 2013. 326(0): p. 10-18.

47. Cooley, H., N. Ajam, and M. Heberger, Key Issues in Seawater Desalination in California: Marine Impacts, 2013, Pacific Institute Oakland, CA.

48. Fuentes-Bargues, J.L., Analysis of the process of environmental impact assessment for seawater desalination plants in Spain. Desalination, 2014. 347: p. 166-174.

49. Latteman, S., Protecting the marine environment, in Seawater Desalination - Conventional and Renewable Energy Processes, A. Cipollina, G. Micale, and L. Rizzuti, Editors. 2009, Springer: Heidelberg.

50. Cooley, H. and M. Heberger, Key Issues in Seawater Desalination in California: Energy and Greenhouse Gas Emissions, 2013, Pacific Institute: Oakland.

51. Cooley, H., N. Ajami, and M. Heberger, Key Issues in Seawater Desalination in California: Marine Impacts, 2013, Pacific Institute Oakland, CA.

52. El Wahab, M.A. and A.Z. Hamoda, EFFECT OF DESALINATION PLANTS ON THE MARINE ENVIRONMENT ALONG THE RED SEA, EGYPT.(CASE STUDY). An International Journal of Marine Sciences, 2012. 28(2): p. 27-36.

53. Poseidon Water, Environmental Impact Report - Environmental Analysis Biological Resources, 2005, Poseidon Water,: Carlsbad.

54. Anderson, E., Drinking water starts flowing from Carlsbad desalination plant, in KPBS2015.

55. San Diego County Water Authority, Seawater Desalination: The Carlsbad Desalination Project, 2014, San Diego County Water Authority,: San Diego.

56. San Diego County Water Authority, Seawater Desalination, 2012.

57. Poseidon Water, Poseidon Resources Marine Life Mitigation Plan 2008, Poseidon Water,: Carlsbad. 
58. California Water Boards, Desalination facility Intakes, Brine Discharges, and the Incorporation of other nonsubstantive changes 2014, State of California, Environmental Protection Agency:

Sacramento,.

59. Poseidon Water. Project Overview: Desalination Plant. 2014 [cited 2015 01/04/15]; Available from: http://carlsbaddesal.com/desalination-plant.

60. Dillman, D.A., J.D. Smyth, and L.M. Christian, Internet, phone, mail, and mixed-mode surveys: the tailored design method. 2014: John Wiley \& Sons.

61. Vaske, J., Survey Research and Analysis: Applications in Parks, Recreation, and Human Dimensions. 2008, State College, PA: Venture Publishing.

62. Connelly, N.A., T.L. Brown, and D.J. Decker, Factors affecting response rates to natural resourcefocused mail surveys: Empirical evidence of declining rates over time. Society \&Natural Resources, 2003. 16(6): p. 541-549.

63. Guzman, G., What is practical knowledge? Journal of Knowledge Management, 2009. 13(4): p. 86-98.

64. Williams, D.R. and J.J. Vaske, The Measurement of Place Attachment: Validity and Generalizability of a Psychometric Approach. Forest Science, 2003. 49(6): p. 830-840.

65. $\mathrm{Xu}, \mathrm{J}$, et al., Local people's perceptions as decision support for protected area management in Wolong Biosphere Reserve, China. Journal of Environmental Management, 2006. 78(4): p. 362372.

66. Jones, N., et al., Visitors' perceptions on the management of an important nesting site for loggerhead sea turtle (Caretta caretta L.): The case of Rethymno coastal area in Greece. Ocean \& Coastal Management, 2011. 54(8): p. 577-584.

67. Little, J., North America's largest seawater desalination plant is ahead of schedule, in abc 10 News2015.

68. Perry, T., Backers of desalination hope Carlsbad plant will disarm critics, in LA Times 2015 .

69. Boxall, B., Seawater desalination plant might be just a drop in the bucket, in LA Times2013.

70. Ressurreição, A., et al., Resident and expert opinions on marine related issues: Implications for the ecosystem approach. Ocean \& Coastal Management, 2012. 69: p. 243-254.

71. Needham, M.D. and C.M. Little, Voluntary environmental programs at an alpine ski area: Visitor perceptions, attachment, value orientations, and specialization. Tourism Management, 2013. 35: p. 70-81.

72. Fletcher, S. and J. Potts, Ocean Citizenship: An Emergent Geographical Concept. Coastal Management, 2007. 35(4): p. 511-524. 
Fig 1: Location of Carlsbad and the desalination plant

Figure 2: Awareness ( $\%$ of respondents, $\mathrm{N}=307$ )

Fig. 3: Self-assessed level of knowledge about the seawater desalination plant in Carlsbad (mean value, $\mathrm{N}=314$ )

Fig. 4: Self-assessed level of knowledge about the seawater desalination plant in Carlsbad (mean value, $\mathrm{N}=314$ )

Measured on a 5 -point scale from $0=$ do not know, $1=$ low, $2=$ moderate, $3=$ high, $4=$ very high level

Fig. 5: Frequency of use and trust in media for learning about the Carlsbad desalination plant

Frequency of use measured on a 3 -point scale from $0=$ never, $1=$ sometimes, $2=$ very often;

Trust measured based on checked 3 most trusted resources

Fig. 6: Frequency of use and trust in source of information for learning about the Carlsbad desalination plant in Carlsbad

Frequency of use measured on a 3 -point scale from $0=$ never, $1=$ sometimes, $2=$ very often;

Trust measured based on checked 3 most trusted resources 


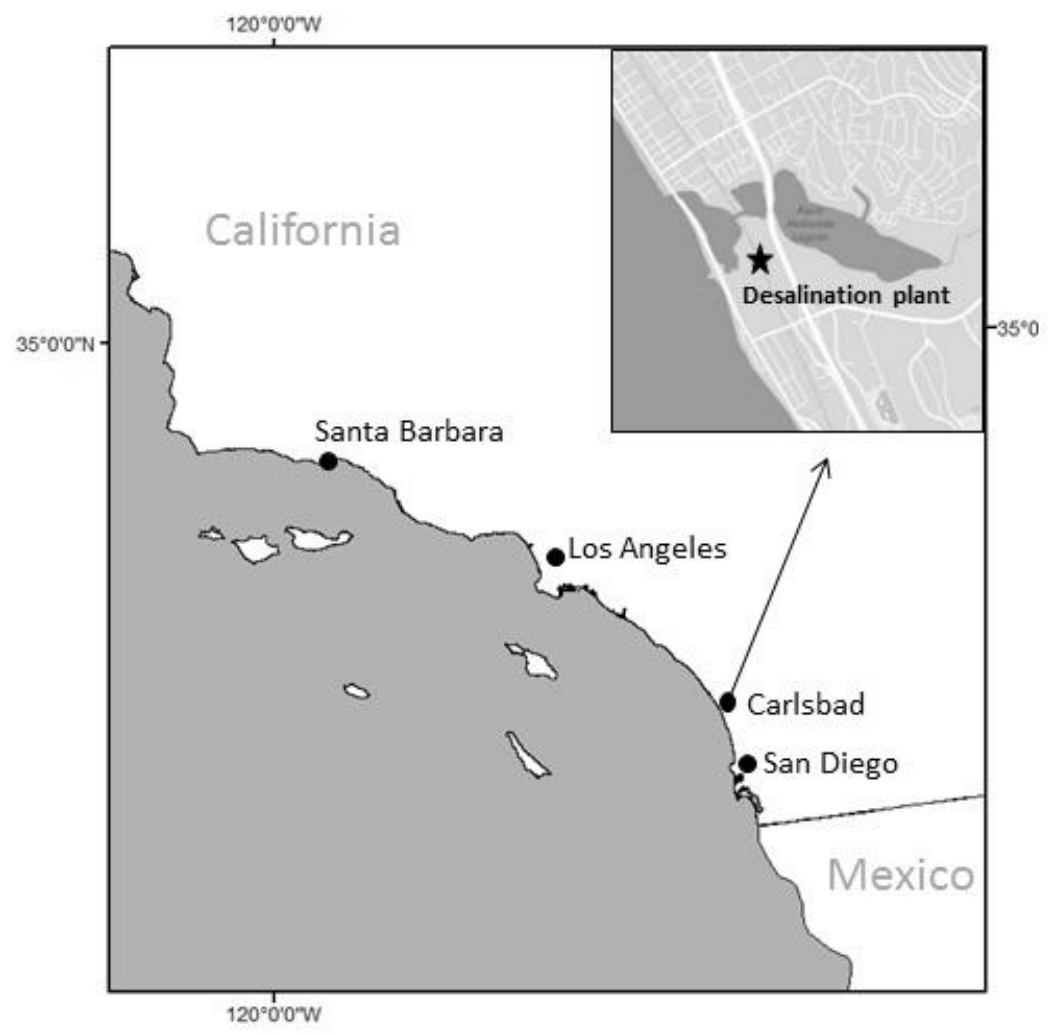




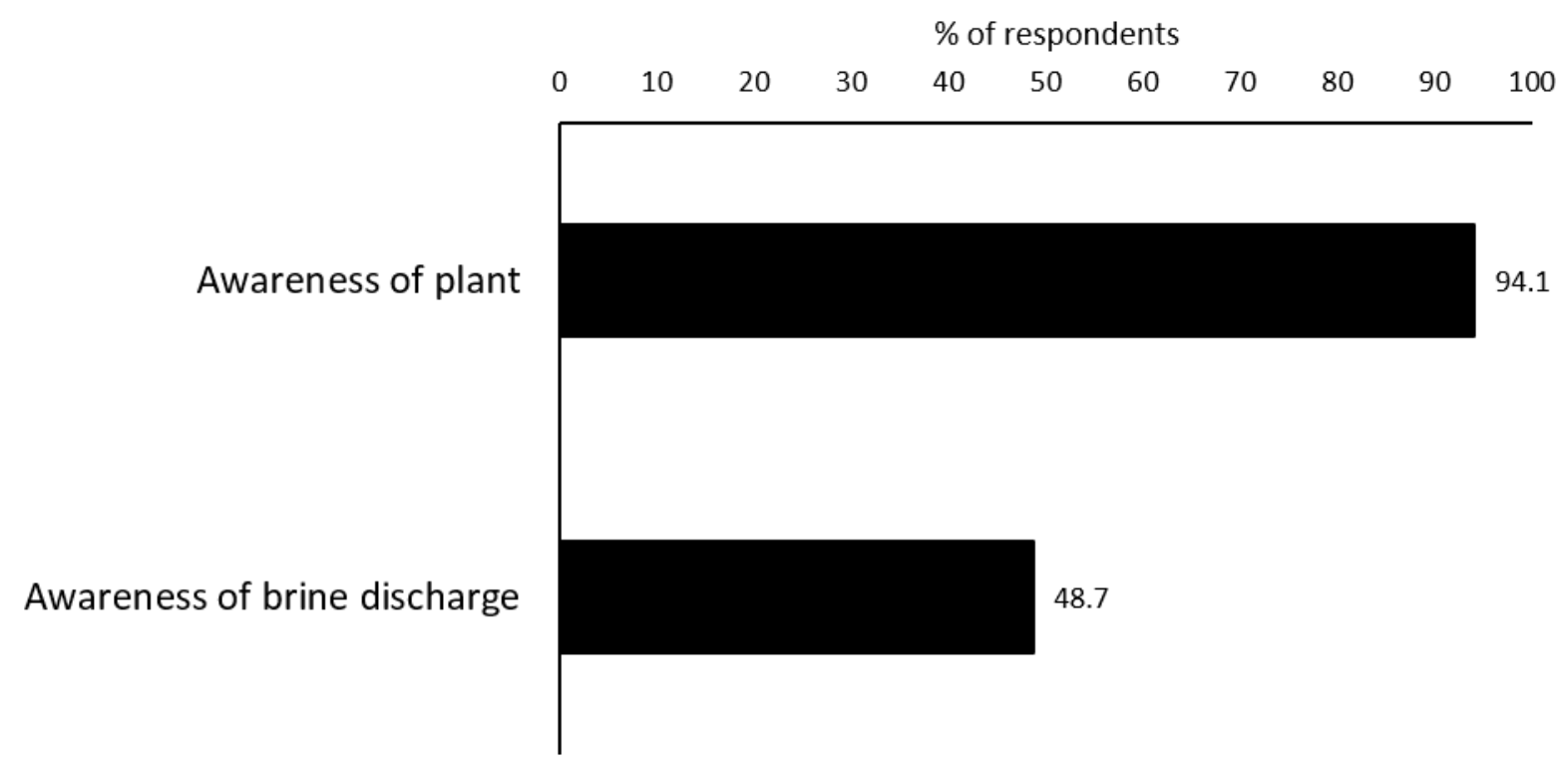



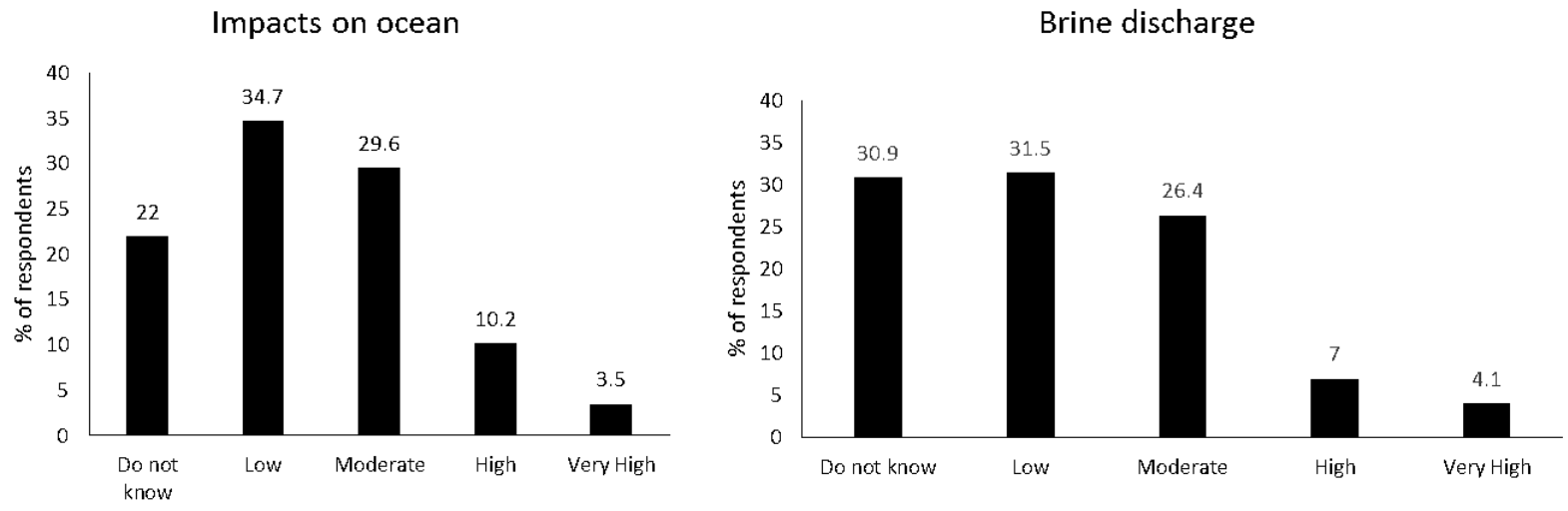

Self-assessed knowledge 


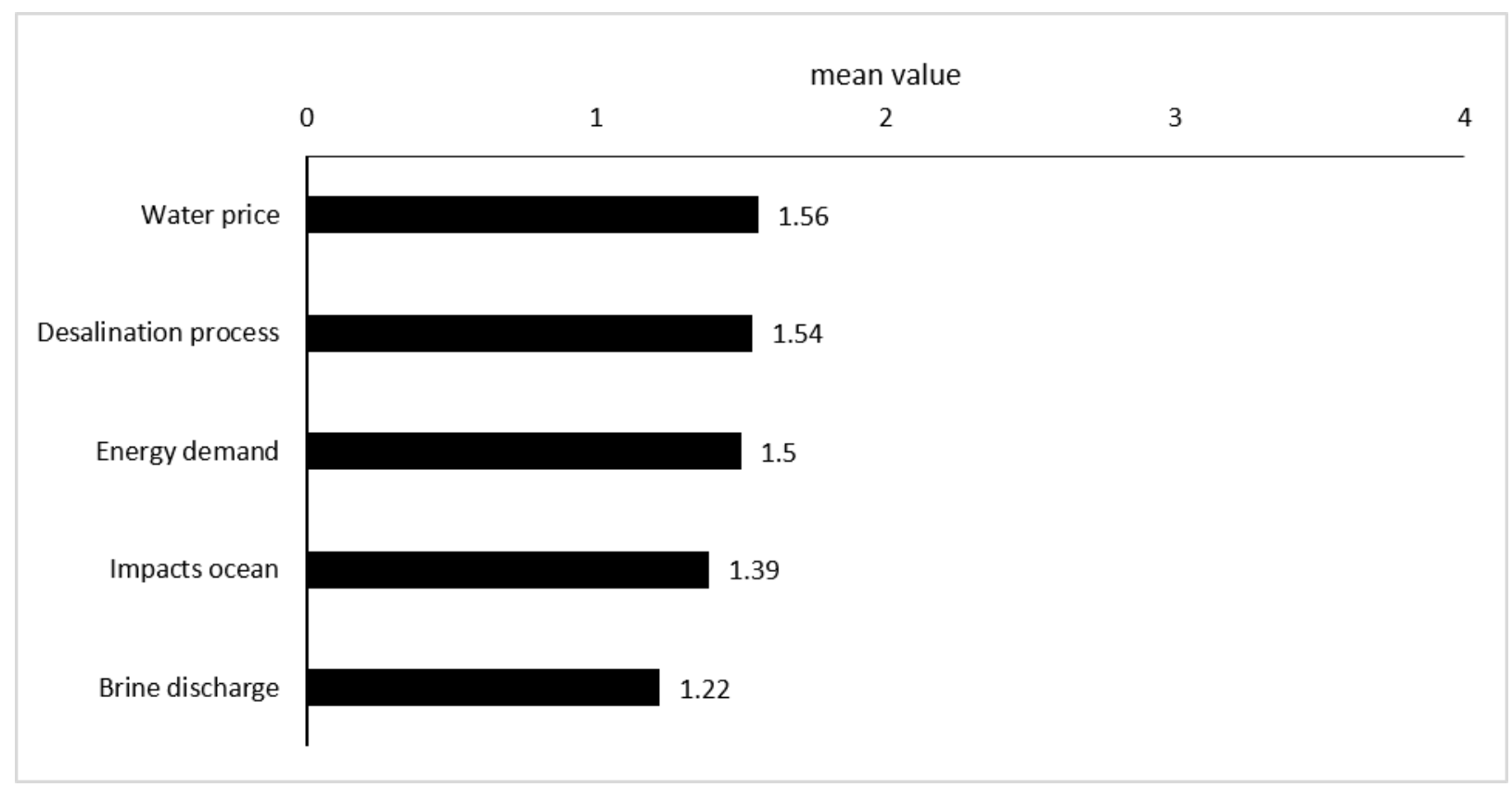




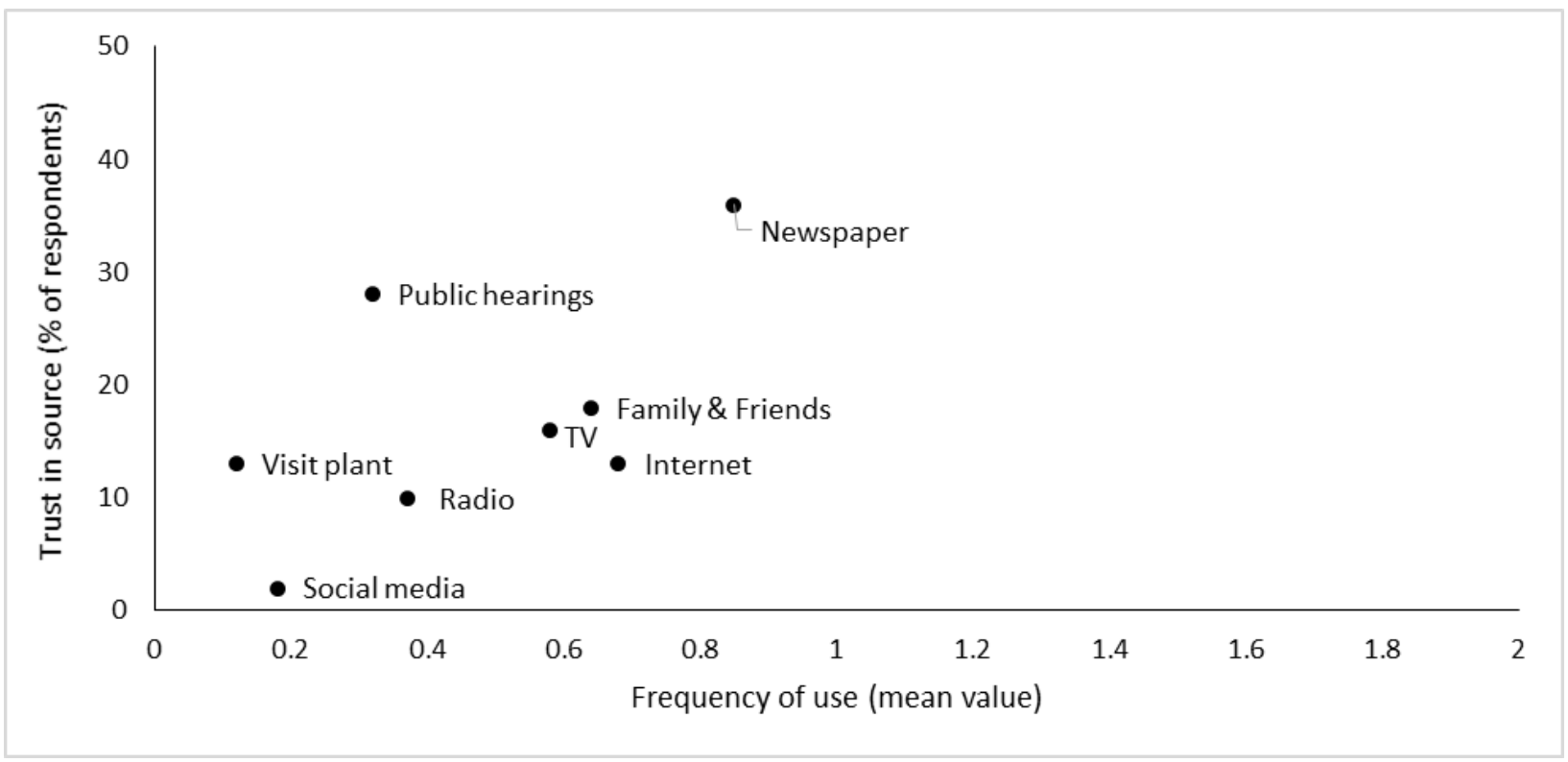




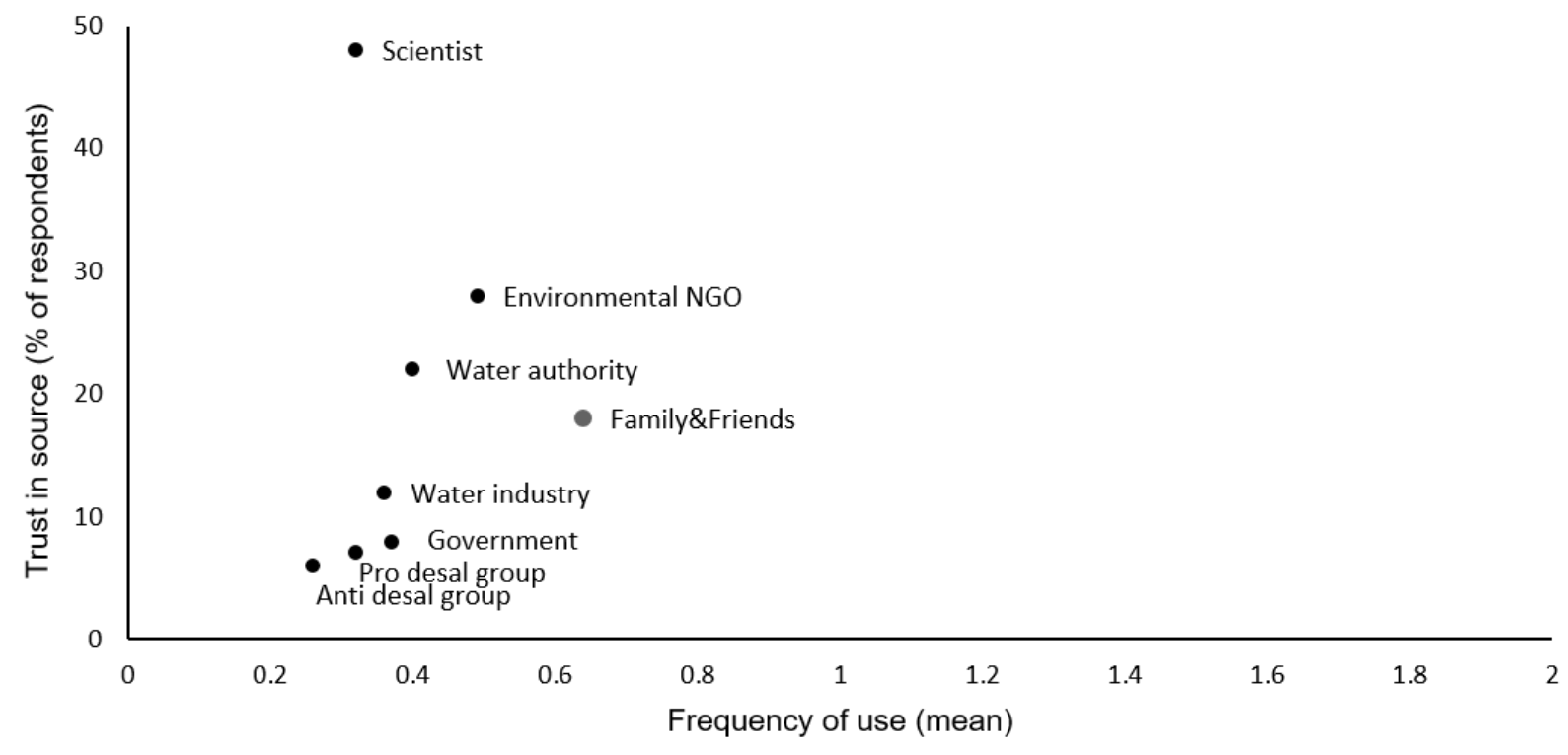


Table 1: Socio-demographic profile of coastal residents in our study ( $N=330)$

\begin{tabular}{llr}
\hline Variable & Coding & Sample \\
\hline Gender & Male (1) & $55.5 \%$ \\
& Female (2) & $44.5 \%$ \\
Age & Continuous & \\
& $18-34$ & 56.9 (mean), Min19, Max=94 \\
& $35-60$ & $9.7 \%$ \\
& $>61$ & $44.8 \%$ \\
Education & Less than high school (1) & $45.5 \%$ \\
& High school (2) & \\
& Associate degree (3) & $1.9 \%$ \\
& Undergraduate (4) & $11.4 \%$ \\
& Graduate (5) & $13.9 \%$ \\
& & $34.0 \%$ \\
& & $38.9 \%$ \\
Years living in Carlsbad & Continuous & $3.97(\mathrm{mean})$ \\
& & \\
& & $11-20(28.2 \%)$ \\
& & $>20(29.4 \%)$ \\
Member NGO & Yes (1) & $12.7 \%$ \\
& No (0) & $87.3 \%$ \\
\hline
\end{tabular}


Table 2: Description and reliability analysis of ocean use and place attachment $(\mathrm{N}=320)$

\begin{tabular}{|c|c|c|c|}
\hline Variable & Mean & SD & Alpha \\
\hline Frequency of ocean use $^{c}$ & 2.44 & 0.70 & 0.785 \\
\hline Fishing & 1.73 & 0.98 & 0.770 \\
\hline Surfing/swimming & 2.83 & 1.26 & 0.713 \\
\hline Boating & 1.91 & 0.97 & 0.746 \\
\hline Wildlife viewing & 3.18 & 1.11 & 0.750 \\
\hline Beach walks & 3.71 & 0.93 & 0.739 \\
\hline Place attachment ${ }^{\mathrm{d}}$ & 4.13 & 0.84 & 0.911 \\
\hline These areas mean a lot to me & 4.51 & 0.83 & 0.818 \\
\hline I am very attached to these marine areas & 4.25 & 0.90 & 0.814 \\
\hline These areas are very special to me & 4.29 & 0.87 & 0.849 \\
\hline $\begin{array}{l}\text { I wouldn't substitute any other area for doing the type of things I do } \\
\text { here }\end{array}$ & 3.99 & 1.13 & 0.881 \\
\hline These areas are the best place for doing what I like to do & 4.00 & 1.07 & 0.881 \\
\hline For the things I enjoy most, no other place can compare & 3.86 & 1.17 & 0.886 \\
\hline
\end{tabular}

\footnotetext{
${ }^{\mathrm{c}}$ Measured on 5-point scale $1=$ Never to $5=$ Almost every day

${ }^{\mathrm{d}}$ Measured on 5-point scale of $1=$ Strongly Disagree to $5=$ Strongly Agree
} 
Table 3: Factual knowledge about brine discharge and the desalination process

\begin{tabular}{|c|c|c|c|c|c|}
\hline & & $\begin{array}{l}\text { Correct } \\
\text { response }\end{array}$ & $\begin{array}{l}\% \text { answer } \\
\text { correctly }\end{array}$ & $\begin{array}{l}\% \text { answer } \\
\text { incorrect }\end{array}$ & $\begin{array}{l}\text { Don’t } \\
\text { know }\end{array}$ \\
\hline \multirow[t]{6}{*}{$\begin{array}{l}\text { Brine } \\
\text { composition }\end{array}$} & $\begin{array}{l}\text { Brine may contain chemicals and heavy } \\
\text { metals }\end{array}$ & Yes & 26.8 & 22.6 & $\overline{50.6}$ \\
\hline & Brine contains salt & Yes & 83.2 & 1.0 & 15.9 \\
\hline & Brine contains dead marine organisms & Yes & 52.2 & 7.1 & 40.7 \\
\hline & Brine has less salt than ocean water & No & 49.0 & 4.5 & 46.5 \\
\hline & $\begin{array}{l}\text { Brine has same } \% \text { of salt than ocean } \\
\text { water }\end{array}$ & No & 44.7 & 7.7 & 47.3 \\
\hline & $\begin{array}{l}\text { Brine will be mixed with more seawater } \\
\text { before it is discharged into the ocean }\end{array}$ & Yes & 27.8 & 4.2 & 68.0 \\
\hline \multirow[t]{2}{*}{$\begin{array}{l}\text { Discharge } \\
\text { location }\end{array}$} & $\begin{array}{l}\text { Brine is discharged in the surf zone (right } \\
\text { off the beach) }\end{array}$ & Yes & 17.6 & 22.4 & 59.9 \\
\hline & $\begin{array}{l}\text { Brine is discharged more than } 1 \text { mile off } \\
\text { shore }\end{array}$ & No & 9.1 & 23.9 & 70.0 \\
\hline \multirow[t]{2}{*}{ Intake } & $\begin{array}{l}\text { More water is taken from the ocean than } \\
\text { the amount of freshwater available after } \\
\text { desalination }\end{array}$ & Yes & 46.2 & 7.4 & 46.5 \\
\hline & $\begin{array}{l}\text { Intake from water to dilute brine kills } \\
\text { fish, plankton, or other marine life }\end{array}$ & Yes & 40.1 & 11.5 & 48.4 \\
\hline Ocean & $\begin{array}{l}\text { Water with more salt than ocean water } \\
\text { floats to the surface }\end{array}$ & No & 22.9 & 21.3 & 55.7 \\
\hline \multicolumn{2}{|c|}{ Total ( $\%$ average score) } & & 38.1 & 12.1 & 50.0 \\
\hline
\end{tabular}


Table 4: Correlations between factual and self-assessed knowledge (Spearman's rho, N=314)

\begin{tabular}{lcc}
\hline & Factual Knowledge brine & Factual Knowledge ocean $^{2}$ \\
\hline $\begin{array}{l}\text { Self-assessed knowledge impact } \\
\text { ocean }\end{array}$ & $.482^{* * *}$ & $.320^{* *}$ \\
$\begin{array}{l}\text { Self-assessed knowledge brine } \\
\text { discharge }\end{array}$ & $.521^{* *}$ & $.305^{* *}$ \\
\hline${ }^{1}$ mean value of self-assessed knowledge measured on 5-point scale from $0=$ do not know to $4=$ very high level of \\
knowledge \\
${ }^{2}$ Mean percentage of correct answers for10 knowledge questions about brine \\
${ }^{3}$ Mean percentage of correct answer to 1 question about behavior of salty water in ocean \\
$* *$ Spearman's rho significance $\mathrm{p}<0.01$ (2-tailed)
\end{tabular}


Table 5 Non-parametric correlation coefficients among 22 independent and 3 knowledge variables

\begin{tabular}{|c|c|c|c|}
\hline & Awareness ${ }^{1}$ & Self-assessed knowledge ${ }^{2}$ & $\begin{array}{r}\text { Factual knowledge } \\
\text { (\# of correct answers) }\end{array}$ \\
\hline \multicolumn{4}{|l|}{ Socio-demographics } \\
\hline Gender & $-.230^{* *}$ & $-.277^{* *}$ & $-.270^{* *}$ \\
\hline Education & -.103 & -.032 & .015 \\
\hline Age & $.136^{*}$ & .108 & -.098 \\
\hline Years in Carlsbad & $.195^{* *}$ & $.234^{* * *}$ & .060 \\
\hline \multicolumn{4}{|l|}{ Situation-specific factors } \\
\hline Member NGO & $.124^{*}$ & $.159^{* *}$ & .102 \\
\hline Frequency ocean use & $.129^{*}$ & $.170^{* *}$ & $.197^{* *}$ \\
\hline Place attachment & -.065 & $-.181^{* *}$ & -0.021 \\
\hline \multicolumn{4}{|l|}{ Information use } \\
\hline $\mathrm{TV}$ & $.262^{* *}$ & $.350^{* *}$ & .059 \\
\hline Newspaper & $.327^{* * *}$ & $.236^{* *}$ & $.197^{* *}$ \\
\hline Internet & $.234^{* * *}$ & $.322^{* *}$ & $.234^{* *}$ \\
\hline Radio & $.258^{* *}$ & $.301^{* *}$ & $.156^{* *}$ \\
\hline Public hearings & $.211^{* *}$ & $.333^{* *}$ & .074 \\
\hline Visit plant & $.128^{*}$ & $.294^{* *}$ & .060 \\
\hline Social media & .041 & .045 & .059 \\
\hline Info Family or friends & $.241^{* *}$ & $.141^{*}$ & .094 \\
\hline Info scientist & $.241^{* *}$ & $.352^{* *}$ & $.181^{* *}$ \\
\hline Water authority & $.295^{* *}$ & $.364^{* *}$ & .107 \\
\hline Environmental NGO & $.163^{* *}$ & $.301^{* *}$ & $.194^{* *}$ \\
\hline Pro-desalination group & $.255^{* *}$ & $.310^{* *}$ & .086 \\
\hline Anti-desalination group & $.243^{* *}$ & $.312^{* *}$ & $.126^{*}$ \\
\hline Water industry & $.292^{* * *}$ & $.343^{* *}$ & $.131^{*}$ \\
\hline Government agency & $.221^{* *}$ & $.289^{* *}$ & $.195^{* *}$ \\
\hline
\end{tabular}

\footnotetext{
$=$ combined awareness of plant and brine discharge

$2=$ self-assessed knowledge of impact on ocean and brine discharge
} 
Table 6 Binary logistic regression coefficients for residents' awareness and self-assessed knowledge

\begin{tabular}{|c|c|c|c|c|c|c|}
\hline & & \multicolumn{3}{|c|}{ Awareness ${ }^{1}$} & \multicolumn{2}{|c|}{ Self-assessed knowledge ${ }^{2}$} \\
\hline & B & S.E. & $\operatorname{Exp}(B)$ & B & S.E. & $\operatorname{Exp}(B)$ \\
\hline Gender & -1.225 & .310 & $.294 * *$ & -1.521 & .337 & $.218 * *$ \\
\hline Years in Carlsbad & .160 & .014 & 1.016 & .024 & .015 & 1.024 \\
\hline Age & .001 & .011 & 1.010 & -.001 & .012 & .999 \\
\hline eNGO & .684 & .429 & 1.983 & -.201 & .396 & .818 \\
\hline Ocean use & -.126 & .257 & .882 & -.357 & .265 & .700 \\
\hline Place attachment & -.049 & .199 & .952 & -.270 & .195 & .763 \\
\hline Information use & 2.610 & .439 & $13.598 * *$ & 3.290 & .526 & $26.844 * *$ \\
\hline Constant & -3.270 & 1.199 & .038 & -2.665 & 1.21 & .070 \\
\hline
\end{tabular}


Table 7 Linear regression coefficients for residents' factual knowledge

\begin{tabular}{lrrrr}
\hline & B & B & Std. Error & Beta \\
\hline Gender & -1.225 & -1.40 & .31 & $-.25^{* *}$ \\
eNGO & .684 & 0.29 & .38 & .44 \\
Ocean use & -.126 & 0.52 & .24 & $.13^{*}$ \\
Place attachment & -.049 & -.171 & .192 & -.053 \\
Information use & 2.610 & 1.32 & .38 & $.20^{* *}$ \\
Constant & -3.270 & 2.93 & .85 & \\
\hline
\end{tabular}


Table 8: Binary logistic regression coefficients for residents' support

\begin{tabular}{llrrr}
\hline & B & \multicolumn{1}{l}{ S.E. } & \multicolumn{1}{l}{ Sig. } & \multicolumn{1}{c}{$\operatorname{Exp}(\mathrm{B})$} \\
\hline Factual knowledge based on \# of correct responses & -.208 & .087 & .016 & .812 \\
Self-assessed knowledge desalination process & .361 & .330 & .275 & 1.435 \\
Self-assessed knowledge ocean impact & -.338 & .300 & .259 & .713 \\
Self-assessed knowledge energy demand & .182 & .305 & .551 & 1.20 \\
Self-assessed knowledge water price & -.011 & .246 & .963 & .989 \\
Self-assessed knowledge brine discharge & -.541 & .330 & .101 & .582 \\
Awareness of plant & .487 & .913 & .594 & 1.627 \\
Awareness of brine & 1.07 & .469 & .022 & 2.915 \\
Constant & 2.45 & .993 & .014 & 11.589 \\
\hline Cox\&Snell $\mathrm{R}^{2}=0.077$, NagelkerkeR
\end{tabular}

